\title{
Risk and protective factors for the development of chronic diseases in nurses
}

Fatores de risco e proteção para o desenvolvimento de doenças crónicas em profissionais de enfermagem

Factores de riesgo y protección para el desarrollo de enfermedades crónicas en profesionales de enfermería

Luciane Peter Grillo*(D); Nadine Rodrigues de Albuquerque**; Nathalia Corrêa Vieira***; Tatiana Mezadri****(D); Leo Lynce Valle de Lacerda*****(iD)

\begin{abstract}
Background: Nurses are at risk of developing chronic diseases because of their long work hours and shift work.

Objective: To identify the risk and protective factors for the development of chronic diseases in nurses based on their work shifts. Methodology: A questionnaire composed of sociodemographic questions and questions on risk and protective factors for the development of chronic noncommunicable diseases was applied to nurses working at a university hospital.

Results: The sample was composed of 75 professionals, mostly women (87\%), married/cohabiting (56\%). The night shift nurses' body mass index was significantly higher than that of day shift nurses $(p=0.045)$. With regard to the risk factors for chronic diseases, a significantly higher prevalence of smokers was found in the night shift $(p=0.034)$.

Conclusion: The results can contribute to the development of strategies for improving the adherence to healthy habits and promoting better living and working conditions for nurses.
\end{abstract}

Keywords: health promotion; chronic disease; nursing; risk factors; night work

\section{Resumo}

Enquadramento: Os profissionais de enfermagem, por terem longas jornadas de trabalho e exercerem as suas atividades em turnos, estão sujeitos a desenvolver doenças crónicas. Objetivo: Identificar os fatores de risco e proteção para o desenvolvimento das doenças crónicas em profissionais de enfermagem, segundo os turnos de trabalho.

Metodologia: Aplicou-se um questionário composto por questóes sociodemográficas e relativas a fatores de risco e proteção para as doenças crónicas não transmissíveis, em profissionais de enfermagem de um hospital universitário.

Resultados: Participaram no estudo 75 profissionais, com predominância do sexo feminino $(86,7 \%)$ e estado civil casado/união de facto (56\%), sendo que o índice de massa corporal dos profissionais do turno da noite era significativamente superior ao dos profissionais do turno diurno $(p=$ $0,045)$. Em relação aos fatores de risco para doenças crónicas, verificou-se prevalência significativamente superior no turno da noite para a variável tabagismo $(p=0,034)$.

Conclusáo: Os resultados poderão subsidiar o desenvolvimento de estratégias para a adesão de hábitos saudáveis, propiciando melhores condiçóes de vida e trabalho aos enfermeiros.

Palavras-chave: promoção da saúde; doença crónica; enfermagem; fatores de risco; trabalho noturno

*Ph.D., Nutritionist, University of Vale do Itajaí, 88302-202, Brazil [grillo@univali.br]. (c) https://orcid.org/0000-0003-3096-5578. Contribution to the article: literature search, dat collection, and article writing. Address for correspondence: Rua Adolfo Sacani, 36 apto, 502 89253-075, Jaraguá do Sul, Brasil.

**Bacharelato, Nutrition student, University of Vale do Itajaí, 88302-202, Brazil [nah.nadineabuquerque $@$ hotmail.com]. Contribution to the article: literature search data collection and article writing.

and* article writing. gmail.com]. Contribution to the article: literature search, data collection, and article writing. *****Ph.D., Nutritionist, University of Vale do Itajai, 88302-202, Brazil [mezadri@ univali.br]. (1) https://orcid.org
and discussion.

**:****Ph.D. Oceanographer Universitv of Vale do Itaiai, 88302-202, Brazil lleolvnce@univali. bri. (1) https://orcid.org/0000-0003-3662-4678. Contribution to the article: statistical treatment and assessment.

\section{Resumen}

Marco contextual: Los profesionales de enfermería, debido a que tienen largas jornadas de trabajo y ejercen sus actividades por turnos, están expuestos a desarrollar enfermedades crónicas.

Objetivo: Identificar los factores de riesgo y protección para el desarrollo de enfermedades crónicas en profesionales de enfermería, según los turnos de trabajo.

Metodología: Se aplicó un cuestionario compuesto por cuestiones sociodemográficas y relativas a los factores de riesgo y protección de las enfermedades crónicas no transmisibles en los profesionales de enfermería de un hospital universitario.

Resultados: En el estudio participaron 75 profesionales, con predominio del sexo femenino $(86,7 \%)$ y estado civil casado/pareja de hecho (56\%). El índice de masa corporal de los profesionales del turno de noche era significativamente superior al de los profesionales del turno de día $(p$ $=0,045)$. En relación a los factores de riesgo de las enfermedades crónicas se verificó prevalencia significativamente superior en el turno de noche para la variable tabaquismo $(p=0,034)$.

Conclusión: Los resultados pueden servir para desarrollar estrategias de adhesión de hábitos saludables, lo que favorece las condiciones de vida y trabajo de los enfermeros.

Palabras clave: promoción de la salud; enfermedad crónica; enfermería; factores de riesgo; trabajo nocturno

Received for publication: 01.03 .18

Accepted for publication: 15.06 .18

Série IV - n. ${ }^{\circ} 18$ - JUL./AGO./SET. 2018 


\section{Introduction}

Chronic noncommunicable diseases are one of the major public health challenges of the $21^{\text {st }}$ century that countries have to address, including low- and middle-income countries, with negative social and economic consequences (World Health Organization [WHO], 2014). This group of diseases, which includes cardiovascular and chronic respiratory diseases, cancer, and diabetes, is the leading cause of death, being responsible for $70 \%$ of deaths worldwide and $73 \%$ in Brazil, corresponding to 928,000 deaths (WHO, 2017). These diseases have modifiable risk factors such as smoking, an unhealthy diet, a sedentary lifestyle, and excessive alcohol consumption, which, in turn, lead to overweight and obesity, raised blood pressure and cholesterol levels, and, ultimately, disease.

Shift work became more common with the Industrial Revolution and the discovery of artificial light, enabling activities to be extended, including into the night hours. With the economic globalization and a continuous 24-hour work cycle, shift work became essential. There are different professionals who work rotating shifts, namely healthcare professionals such as nurses. In Brazil, these professionals, particularly those who work in hospital settings, have long days of work and are exposed to precarious working conditions which "has several consequences, such as work-related accidents and diseases. This situation is due to a range of factors such as unsanitary working conditions, overload, and professional burnout" (Rodrigues \& Araújo, 2016, p. 19).

This study is justified by the high number of healthcare professionals who, due to working long shifts, have an increased risk of developing diseases such as chronic noncommunicable diseases. Shift work implies changing and adapting the daily biological rhythm due to the mere fact of changing the rest hour from night into day. The body undergoes a transformation which leads to sleep disorders, an inadequate diet, and risk factors for chronic noncommunicable diseases (Coelho, Pinto, Mota, \& Crispim, 2014; Malta et al., 2015). This topic was chosen because these professionals are responsible for caring for the health of others but often neglect their own health. Thus, this study aimed to identify the prevalence of risk and protective factors for the development of chronic diseases in a sample of nurses, based on their work shifts, at a hospital in the municipality of Itajaí, in southern Brazil.

\section{Background}

Several studies on occupational health have tried to understand the dynamics of the health-disease process by analyzing the relationship between the worker and the work environment. The health system has come late to the issues of workload, obligations, and risks to which workers are exposed (Araújo, 2015).

Nurses work long hours, have poor sleep quality and lack of rest, and work shifts on weekends and extra hours, which compromises the recovery of their physical-motor and cognitive function due to, for example, changes in the speed/ precision relationship in routine procedures and the decline in memory and attention (Machado et al., 2018). These changes are harmful to human health because continuous circadian rhythm imbalances lead to gastrointestinal, psychological (e.g., stress), and metabolic (e.g., obesity and chronic diseases) alterations. In addition, they affect the professionals' family and social life, hindering their participation in social activities (Pepłońska et al., 2014; Fernandes, Ribeiro, Borges, de Galiza, \& Joventino, 2017).

One of the consequences of the predominance of women in the nursing workforce is the additional time spent on housework every day, creating difficulties in reconciling personal and professional life which can further deepen the physical, nutritional, and psychosocial imbalances. These include those that are associated with the night shift work, namely obesity (Siqueira et al., 2015), which is one of the risk factors for chronic noncommunicable diseases.

Today, chronic noncommunicable diseases are the leading causes of disability and mortality "in the world population, besides being responsible for the high economic burden on individuals, societies, and health systems" (Malta et al., 2015, p. 374). For these reasons, in 2006, the Secretary of Health Surveillance, under the Brazilian Ministry of Health, implemented the Surveillance System of Risk and Protective Factors for Chronic Diseases by Telephone Survey (Sistema de Vigilância de Fatores de Risco e Proteção para Doenças Crónicas por Inquérito Telefónico, VIGITEL), which is done every year to monitor risk 
and protective factors for chronic diseases in all Brazilian capitals. VIGITEL has selected important indicators to determine the global burden of disease as estimated by the WHO Region of the Americas (WHO, 2014). Among the risk factors are smoking, overweight, consumption of soft drinks, sweets, and foods high in saturated fat, replacing meals with snacks, spending more than 3 hours watching TV and using tablets, drinking alcoholic beverages, a medical diagnosis of hypertension, diabetes, dyslipidemia, and self-reported poor health status. Among the protective factors are physical activity, consumption of fruits, vegetables, and beans, and examinations for the early detection of common types of cancer in women (mammography and Pap tests for cervical cancer; Ministério da Saúde, 2017).

\section{Research question}

Is there a difference between work shifts concerning the risk and protective factors for the development of chronic diseases in nurses?

\section{Methodology}

A quantitative, cross-sectional, descriptive, and analytical study was conducted.

The research was conducted at a hospital in the municipality of Itajaí, state of Santa Catarina, in southern Brazil. The municipality has a population of 183,373 inhabitants.

All of the nurses in this hospital were invited to participate in the study. These nurses worked 6-hour rotating shifts with 18 hours of rest or 12-hour shifts with 36 hours of rest. Shifts were subdivided into three periods: from 7 a.m. to 1 p.m., from 1 p.m. to 7 p.m., and from 7 p.m. to 7 a.m. In this study, the professionals were divided into two groups: day shift (those who worked from 7 a.m. to 7 p.m.) and night shift (those who worked from 7 p.m. to 7 a.m.). The inclusion criteria were being a nurse and working for at least 6 months at that hospital, being excluded those nurses who were on vacation or medical leave.

Data were collected in the second half of 2017 through the application of a structured questionnaire, with multiple choice questions, by two qualified healthcare professionals who had received previous training for this purpose and were supervised. The questionnaire was composed of demographic data (age, gender, and marital status) and risk and protective factors for chronic diseases assessed using VIGITEL (Ministério da Saúde, 2017). Risk factors included: smoking; overweight and obesity; consumption of unhealthy foods (meat with visible fat, whole milk, artificial drinks, regular consumption of sweets, replacing meals with snacks); spending more than 3 hours watching TV and using tablets/computers/phones; excessive alcohol consumption; self-reported poor health status; and medical diagnosis of hypertension, diabetes, and dyslipidemia. Protective factors included: healthy eating patterns (fruits, vegetables, and beans); physical activity; Pap test for cervical cancer in the past 3 years for women aged 25 to 64 years and mammography in the past 2 years for women aged 50 to 69 years.

Data were collected and analyzed using Microsoft Excel. For data analysis, the groups with overweight and obesity were clustered and defined as overweight. Descriptive statistics were used, absolute and relative frequencies were calculated, and inferential statistics were estimated using Fisher's exact test and the Student's t-test. The associations between the sociodemographic and anthropometric characteristics and the risk and protective factors and the work shifts were analyzed.

This study complied with Resolution No. 466/12 of the National Health Council for research involving human beings and was approved by the Research Ethics Committee of the University of Vale do Itajaí under protocol 2.179.239. Participants signed an informed consent form, which described the study phases and the researchers ensured data confidentiality. Based on the results obtained, individual cards with the anthropometric assessment were elaborated and educational materials were developed with guidelines on how to avoid the main risk factors and increase protection against chronic diseases.

\section{Results}

Seventy-five professionals participated in this study, which corresponded to $74 \%$ of the nurses working at the hospital: 31 (41\%) from the day shift and $44(59 \%)$ from the night shift. Most of the nurses were women $(n=$ 
$65 ; 86.7 \%)$ and lived in cohabitation $(n=42$; $56 \%$ ); however, no statistical difference was found between the work shifts and gender and marital status (Table 1).

Table 1

Nurses' sociodemographic characteristics, by shift

\begin{tabular}{lcccc}
\hline \multirow{2}{*}{$\begin{array}{l}\text { Sociodemographic } \\
\text { characteristics }\end{array}$} & $\begin{array}{c}\text { Day }(n=31) \\
n(\%)\end{array}$ & $\begin{array}{c}\text { Night }(n=44) \\
n(\%)\end{array}$ & \multirow{2}{*}{$\begin{array}{c}\text { Total } \\
n(\%)\end{array}$} \\
\cline { 2 - 3 } $\begin{array}{l}\text { Gender } \\
\text { Male }\end{array}$ & $3(10.0)$ & $7(16.0)$ & 0.509 & $10(13.3)$ \\
Female & $28(90.0)$ & $37(84.0)$ & & $65(86.7)$ \\
\hline Marital status & $13(42.0)$ & $20(45.0)$ & 0.762 & $33(44.0)$ \\
Single & $18(58.0)$ & $24(55.0)$ & $42(56.0)$ \\
\hline Cohabiting & & &
\end{tabular}

Note. ${ }^{*} p=$ Significance level (Fisher's Exact Test).

In relation to the anthropometric variables, no difference was observed between the shifts in the variables age, weight, and height, but the mean body mass index in both groups was classified as overweight. These results were significantly higher among night shift nurses than among day shift nurses $(p=$ 0.045; Table 2).

Table 2

Nurses' anthropometric characteristics, by shift

\begin{tabular}{|c|c|c|c|}
\hline \multirow[b]{2}{*}{$\begin{array}{l}\text { Anthropometric } \\
\text { characteristics }\end{array}$} & \multicolumn{2}{|c|}{ Shift } & \multirow[b]{2}{*}{$p^{*}$} \\
\hline & $\begin{array}{c}\text { Day }(n=31) \\
\text { Mean }(95 \% \mathrm{CI})\end{array}$ & $\begin{array}{l}\text { Night }(n=44) \\
\text { Mean }(95 \% \mathrm{CI})\end{array}$ & \\
\hline Age (years) & $36.4(32.59-40.31)$ & $38.6(36.06-40.98)$ & 0.3387 \\
\hline Weight (kg) & $72.5(66.66-78.36)$ & $77.1(72.38-81.80)$ & 0.862 \\
\hline Height (m) & $1.59(1.57-1.62)$ & $1.62(1.59-1.64)$ & 0.335 \\
\hline BMI $\left(\mathrm{kg} / \mathrm{m}^{2}\right)$ & $28.5(25.92-31.14)$ & $29.2(27.70-30.78)$ & 0.045 \\
\hline
\end{tabular}

Note. $\mathrm{BMI}=$ Body mass index; $\mathrm{CI}=$ Confidence interval; ${ }^{*} p=$ Significance level (Student's t-test).

Risk factors for chronic diseases were found in both groups; however, the number of smokers was significantly higher in the night shift than in the day shift ( $p=0.034$; Table 3$)$. 
Table 3

Risk factors for chronic noncommunicable diseases among nurses, by shift

\begin{tabular}{|c|c|c|c|}
\hline \multirow[b]{2}{*}{ Risk factors } & \multicolumn{2}{|c|}{ Shift } & \multirow[b]{2}{*}{$p^{*}$} \\
\hline & $\begin{array}{l}\text { Day }(n=31) \\
\quad n(\%)\end{array}$ & $\begin{array}{l}\text { Night }(n=44) \\
n(\%)\end{array}$ & \\
\hline Consumption of meat with excess fat & $10(30.3)$ & $23(69.7)$ & 0.086 \\
\hline Consumption of artificial drinks & $8(34.8)$ & $15(65.2)$ & 0.444 \\
\hline Consumption of whole milk & $18(40.0)$ & $27(60.0)$ & 0.774 \\
\hline Excessive consumption of sweets & $8(32.0)$ & $17(68.0)$ & 0.246 \\
\hline Replacement of meals with snacks & $5(45.4)$ & $6(54.6)$ & 0.764 \\
\hline Excessive alcohol consumption & $5(31.2)$ & $11(68.8)$ & 0.356 \\
\hline Spending more than 3 hours a day watching TV & $5(27.8)$ & $13(72.2)$ & 0.180 \\
\hline $\begin{array}{l}\text { Spending more than } 3 \text { hours a day using tablets } \\
\text { more than } 3 \text { hours a day }\end{array}$ & $15(44.1)$ & $19(55.9)$ & 0.656 \\
\hline Smoking & $2(14.3)$ & $12(85.7)$ & 0.034 \\
\hline Poor health status & $5(33.3)$ & $10(66.7)$ & 0.482 \\
\hline Hypertension & $7(53.8)$ & $6(46.2)$ & 0.314 \\
\hline Diabetes & $1(33.3)$ & $2(66.7)$ & 1.000 \\
\hline Dyslipidemia & $2(18.2)$ & $9(81.8)$ & 0.110 \\
\hline Overweight & $23(39.7)$ & $35(60.3)$ & 0.590 \\
\hline
\end{tabular}

Note. ${ }^{*} p=$ Significance level (Pearson's Chi-squared Test).

No statistically significant difference was found between work shifts regarding protec-

tive factors for chronic noncommunicable diseases (Table 4).

Table 4

Protective factors for chronic noncommunicable diseases among nurses, by shift (day: $n=31$ and night: $n=44$ )

\begin{tabular}{lccc}
\hline & \multicolumn{3}{c}{ Shift } \\
\cline { 2 - 3 } Protective factors & $\begin{array}{c}\text { Day } \\
n(\%)\end{array}$ & $\begin{array}{c}\text { Night } \\
n(\%)\end{array}$ & $p^{*}$ \\
\hline Consumption of beans & $9(39.1)$ & $14(60.9)$ & 0.797 \\
Regular consumption of fruits/vegetables & $24(44.4)$ & $30(55.6)$ & 0.380 \\
Recommended consumption of fruits/vegetables & $3(50.0)$ & $3(50.0)$ & 0.687 \\
Physical activity & $9(52.9)$ & $8(47.1)$ & 0.269 \\
Pap test & $22(88.0)$ & $32(86.5)$ & 0.166 \\
Mammography $^{\mathrm{b}}$ & $3(100.0)$ & $3(60.0)$ & 0.695 \\
\hline
\end{tabular}

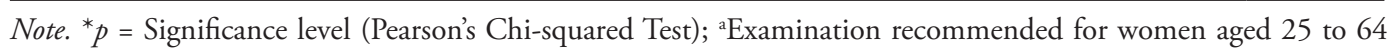
years ( $n=25$ in the day shift and $n=37$ in the night shift); ${ }^{\mathrm{b}}$ Examination recommended for women aged 50 to 69 years ( $n=3$ in the day shift and $n=5$ in the night shift). 


\section{Discussion}

In relation to the nurses' sociodemographic profile, there was a predominance of women. This prevalence reflects a trend in the profession due to sociohistorical factors related to the performance of activities involving caring for others. Similar results were found in other studies conducted in Brazil (Lima et al., 2013; Porto et al., 2013; Machado et al., 2018; Magalhães et al., 2014; Silva, Schmidt, Noal, Signor, \& Gomez, 2016; Siqueira et al., 2015). As regards the marital status, most of the nurses were married/cohabiting, which is similar to the result found in another study in which being married or cohabiting was a protective mechanism against physical and psychological diseases (Machado Rodrigues, Oliveira, Laudano, \& Nascimento Sobrinho, 2014). On the other hand, studies also show a higher prevalence of single nurses, claiming that this characteristic ensures greater availability to work, without commitments related to domestic chores, partners, and children (Magalhães et al., 2014; Porto et al., 2013).

"Night shift workers' weight gain can result from the lack or reduction of physical activity, particularly in the day after the night shift, because of the need to sleep and the physical and mental burnout" (Siqueira et al., 2015, p. 1932). This study showed that night shift nurses had a significantly higher body mass index but showed no significant difference between shifts and physical activity. In a study on the body mass index of 90 nurses who worked both day and night shifts, the authors found a body mass index significantly higher among night shift workers (Silveira, Urbanetto, Silva, Magnago, \& Poli-de-Figueiredo, 2013), which is a result similar to that of this study.

Night shifts, due to changes in work schedules, affect workers' chronobiology. In a daytime routine, various biological processes, such as the sleep/wake cycle, food intake, metabolism, and secretion of the leptin and ghrelin hormones, have circadian rhythms through which the body adapts, promoting day activity and night rest. To explain the higher body mass index among night shift workers, when compared to day shift workers, the same author proposed a theory in which light exposure at night could contrib- ute to a decrease and/or delay in the secretion of leptin and an increase in appetite, food intake, and, consequently, ghrelin levels, leading to weight gain (Antunes, Levandovski, Dantas, Caumo, \& Hidalgo, 2010).

In a literature review covering the period from 2002 to 2014, the authors addressed the influence of shift work on nurses' nutritional profile and sleep pattern and found a high prevalence of overweight, probably due to exposure to multiple risk factors such as worse sleep quality and eating habits with the purpose of adapting to the work routine (Coelho et al., 2014). In a study aimed to identify the risk factors for cardiovascular diseases among nurses working at a public hospital in Fortaleza, northeastern Brazil, the authors found that $90.9 \%(n=150)$ of nurses were overweight (Magalhães et al., 2014).

Based on the analyzed sample, among the factors which may pose considerable risks for the development of chronic noncommunicable diseases in nurses, as well as increased body mass index, the night shift group had a significant prevalence of smokers, which is an important risk factor for several chronic diseases such as cardiovascular diseases (Baumgartel, Onofrei, Lacerda, Grillo, \& Mezadri, 2016). In line with the results from this study, Pimenta, Kac, Souza, Ferreira, and Silqueira (2012) aimed to estimate the association between night shift work and high cardiovascular risk among the employees of a public university in the state of Minas Gerais, southeastern Brazil, and found a higher percentage of smokers in the night shift (17.3\%), when compared to the day shift (9.2\%). Therefore, night shift work potentially increases the risk of cardiovascular diseases. In another study, $11 \%$ of night shift nurses were smokers $(n=$ 18; Magalhães et al., 2014).

Meat is a source of protein of high biological value, B-complex vitamins, and minerals such as iron; however, excessive consumption should be avoided because it also provides significant amounts of saturated fats. According to VIGITEL, "one third $(32.0 \%)$ of the studied Brazilian adult population reported eating meat with excess fat" (Ministério da Saúde, 2017, p. 64). In this study, night shift workers ate more meat with excess fat than day shift workers $(p=0.086)$. 
When comparing the prevalence of risk factors for chronic diseases in this study with data published in the last VIGITEL (Ministério da Saúde, 2017), this study showed a higher prevalence of the variables related to the consumption of meat with excess fat, artificial drinks, whole milk, replacement of meals with snacks, excessive consumption of alcohol and sweets, spending more than 3 hours watching TV, spending more than 3 hours using tablets/computers/phones, smoking, hypertension, diabetes, poor health status, and overweight.

In relation to the protective factors for chronic diseases, no significant differences were found between the work shifts; however, when compared to data from the last VIGITEL (Ministério da Saúde, 2017), this study showed a lower prevalence of the variables related to the consumption of beans, physical activity, recommended consumption of fruits, vegetables, and greens, and mammography examination. Two limitations of this study were the regional results and the population size in both analyzed groups, making it difficult to analyze data based on age and gender. Nonetheless, the data obtained in this study reflect the reality of this population group which partly corresponds to the reality of the country in relation to the risk and protective factors for the development of chronic diseases.

\section{Conclusion}

The results of this study show a predominance of women and the cohabiting/married status in this professional group. Both groups had risk factors for chronic diseases, although there was a higher body mass index and prevalence of smoking among night shift nurses, suggesting that working during this period can affect these workers health. Both overweight and smoking are precursors of chronic noncommunicable diseases: cardiovascular and chronic respiratory diseases, cancer, and diabetes.

Although the work of night shift nurses is essential, we suggest that the institutions promote a better adaptation of the work to these professionals, namely by giving them time to rest and promoting healthy environments. This study is relevant because, besides showing the reality of this professional group which is dedicated to caring for human health, it shows nurses' self-care difficulties. The results may contribute to the development of interventions aimed at raising awareness, through educational programs, to the importance of healthy habits for health promotion, thus reducing the alarming morbidity and mortality rates associated with chronic diseases, which usually evolve silently, as well as early identification of the risk factors for these diseases. These strategies will provide better living and working conditions for nurses and, consequently, improve care delivery.

Financial support: PIBIC/CNPq.

\section{References}

Antunes, L. C., Levandovski, R., Dantas, G., Caumo, W., \& Hidalgo, M. P. (2010). Obesity and shift work: Chronobiological aspects. Nutrition Research Reviews, 23(1), 155-168. doi:10.1017/S0954422410000016

Araújo, S. N. (2015). Os riscos enfrentados pelos profissionais de enfermagem no exercício da atividade laboral. Revista Enfermagem Contemporânea, 4(2), 237-243. doi:10.17267/2317-3378rec.v4i2.522

Baumgartel, C., Onofrei, M., Lacerda, L. L., Grillo, L. P., \& Mezadri, T. (2016). Fatores de risco e proteção de doenças crônicas em adultos: Estudo de base populacional em uma cidade de médio porte no sul do Brasil. Revista Brasileira de Medicina de Familia e Comunidade, 11(38), 1-13. Retrieved from https://www.rbmfc. org.br/rbmfc/article/view/1248/828

Coelho, M. P., Pinto, O. O., Mota, M. C., \& Crispim, C. A. (2014). Prejuízos nutricionais e distúrbios no padrão de sono de trabalhadores da enfermagem. Revista Brasileira de Enfermagem, 67(5), 832-842. doi:10.1590/0034-7167.2014670523

Fernandes, B. K., Ribeiro, A. C., Borges, C. L., de Galiza, F. T., \& Joventino, E. S. (2017). Influências do trabalho noturno no sono dos trabalhadores de enfermagem: Revisão integrativa. Revista Enfermagem Atual, 81, 97-103. Retrieved from https://www.researchgate.net/ publication/317926885_Influencias_do_trabalho_ noturno_no_sono_dos_trabalhadores_de_enfermagem_revisao_integrativa_Influences_of_night_shifts_ in_sleeping_of_nursing_workers_integrative_review

Lima, E. D., Borges, J. V., Oliveira, E. R., Velten, A. P., 
Primo, C. C., \& Leite, F. M. (2013). Qualidade de vida no trabalho de enfermeiros de um hospital universitário. Revista Eletrônica de Enfermagem, 15(4), 1000-1006. doi:10.5216/ree.v15i4.19546

Machado, D. A., Figueiredo N. M., Velasques L. S., Bento C. A., Machado W. C., \& Vianna L. A. (2018). Cognitive changes in nurses working in intensive care units. Revista Brasileira de Enfermagem, 71(1), 73-79. doi:10.1590/0034-7167-2016-0513

Machado, L. S., Rodrigues, E. P., Oliveira, L. M., Laudano, R. C., \& Nascimento Sobrinho, C. L. (2014). Agravos à saúde referidos pelos trabalhadores de enfermagem em um hospital público da Bahia. Revista Brasileira de Enfermagem, 67(5), 684-691. doi:10.1590/00347167.2014670503

Magalhães, F. J., Mendonça, L. B., Rebouças, C. B., Lima, F. E., Custódio, I. L., \& Oliveira, S. C. (2014). Fatores de risco para doenças cardiovasculares em profissionais de enfermagem: Estratégias de promoção da saúde. Revista Brasileira de Enfermagem, 67(3), 394-400. doi:10.5935/0034-7167.20140052

Malta, D. C., Campos, M. O., Oliveira, M. M., Iser, B. P., Bernal, R. T., Claro, R. M., ... Reis, A. A. (2015). Prevalência de fatores de risco e proteção para doenças crônicas não transmissíveis em adultos residentes em capitais brasileiras, 2013. Epidemiologia e Serviços de Saúde, 24(3), 373-387. doi:10.5123/S167949742015000300004

Ministério da Saúde. (2017). Vigitel 2016: Vigilância de fatores de risco e proteção para doenças crônicas por inquérito telefônico. Brasília, Brasil: Autor. Retrieved from http://portalarquivos2.saude.gov.br/images/ pdf/2018/marco/02/vigitel-brasil-2016.pdf

Pepłońska, B., Burdelak, W., Krysicka, J., Bukowska, A., Marcinkiewicz, A., Sobala, W., ... Rybacki, M. (2014). Night shift work and modifiable lifestyle factors. International Journal of Occupational Medicine and Environmental Health, 27(5), 693-706. doi:10.2478/ s13382-014-0298-0

Pimenta, A. M., Kac, G., Souza, R. R., Ferreira, L. M., \& Silqueira, S. M. (2012). Trabalho noturno e risco cardiovascular em funcionários de universidade pública. Revista da Associação Médica Brasileira, 58(2), 168177. doi:10.1590/S0104-42302012000200012

Porto, A. R., Rodrigues, S. D., Joner, L. R., Noguez, P. T., Thofehrn, M. B., \& Dal Pai, D. (2013). Autoavaliação de saúde e doenças crônicas entre enfermeiros de Pelotas/RS. Revista Eletrônica de Enfermagem, 15(3), 763-771. doi:10.5216/ree.v15i3.18008

Rodrigues, L. F., \& Araújo, J. S. (2016). Absenteísmo entre os trabalhadores de saúde: Um ensaio à luz da medicina do trabalho. Revista Ciência e Estudos Acadêmicos de Medicina, 1(5), 10-21. Retrieved from https:// periodicos.unemat.br/index.php/revistamedicina/ article/view/1130/1369

Silva, L. A., Schmidt, S. M., Noal, H. C., Signor, E., \& Gomes, I. E. (2016). Avaliação da educação permanente no processo de trabalho em saúde. Trabalho, Educação e Saúde, 14(3), 765-781. doi:10.1590/19817746-sol00015

Silveira, C. D., Urbanetto, J. S., Silva, P. C., Magnago, T. S., \& Poli-de-Figueiredo, C. E. (2013). Perfil de sobrepeso e obesidade em trabalhadores de enfermagem em unidades de cuidado intensivo e emergência. $R e-$ vista Ciência \& Saúde, 6(3), 157-162. doi:10.15448/ 1983-652X.2013.3.14550

Siqueira, K., Griep, R. H., Rotenberg, L., Costa, A., Melo, E., \& Fonseca, M. D. (2015). Inter-relaçóes entre o estado nutricional, fatores sociodemográficos, características de trabalho e da saúde em trabalhadores de enfermagem. Ciência \& Saúde Coletiva, 20(6), 19251935. doi:10.1590/1413-81232015206.00792014.

World Health Organization. (2014). Global status report on noncommunicable diseases. Geneva, Switzerland: Author. Retrieved from http://apps.who.int/iris/ bitstream/handle/10665/148114/9789241564854_ eng.pdf;jsessionid=B2BCC5E0D3D68EA6AB697C89BD24CEC8? sequence $=1$

World Health Organization. (2017). Noncommunicable diseases progress monitor. Geneva, Switzerland: Author. Retrieved from http://www.who.int/nmh/publications/ncd-progress-monitor-2017/en/ 